E3S Web of Conferences 1, 19006 (2013)

DOI: $10.1051 / \mathrm{e} 3$ sconf/20130119006

(c) Owned by the authors, published by EDP Sciences, 2013

\title{
Heavy metals biogeochemistry in abandoned mining areas
}

\author{
P. J. C. Favas ${ }^{1,3}$ and J. Pratas ${ }^{2,3}$ \\ ${ }^{1}$ Department of Geology, University of Trás-os-Montes e Alto Douro, Vila Real, PORTUGAL, pjcf@utad.pt \\ ${ }^{2}$ Department of Earth Sciences, University of Coimbra, Coimbra, PORTUGAL \\ ${ }^{3}$ IMAR-CMA Marine and Environmental Research Centre, University of Coimbra, Coimbra, PORTUGAL
}

\begin{abstract}
Plants growing on the abandoned Portuguese mines, highly contaminated with $\mathrm{W}, \mathrm{Sn}, \mathrm{As}, \mathrm{Cd}, \mathrm{Cu}$, $\mathrm{Zn}$ and $\mathrm{Pb}$, have been studied for their biogeochemical indication/prospecting and mine restoration potential. The results of analysis show that the species best suited for biogeochemical indicating are: aerial tissues of Halimium umbellatum (L.) Spach, for As and W; leaves of Erica arborea L. for Bi, Sn, W and mostly $\mathrm{Pb}$; stems of Erica arborea $\mathrm{L}$. for $\mathrm{Pb}$; needles of Pinus pinaster Aiton and aerial tissues of Pteridium aquilinum (L.) Kuhn for W; and leaves of Quercus faginea Lam. for Sn. The aquatic plant studied (Ranunculus peltatus Schrank) can be used to decrease the heavy metals, and arsenic amounts into the aquatic environment affected by acid mine drainages.
\end{abstract}

Key words: Acid mine drainage, bioaccumulation, bioindicating, mine restoration, native plants, soils

\section{Introduction}

The purpose and methodological procedures of this study essentially aims: - to characterize the biogeochemical signature of $\mathrm{Sn}, \mathrm{W}$ and associated metal, in soils and plants, of the selected mining areas; - to identify vegetable species or parts of these, indicators of excessive chemical elements present in the natural and mining soils; - to select vegetation species for potential use in bioindication contamination actions and of environmental recovery of tailings and degraded mining areas with similar mineral paragenesis of the studied areas.

In order to offer a general panoramic of the most representative types of $\mathrm{Sn}$ and $\mathrm{W}$ mines in Portugal, areas were selected according to mineralization and environmental factors: Ervedosa Mine with cassiterite and diverse sulphides; Rio de Frades Mine and Regoufe Mine with wolframite, scheelite, cassiterite and sulphides; Adoria Mine with volframite, cassiterite and sulphides; and Tarouca Mine with scheelite, cassiterite and sulphides.

\section{Materials and Methods}

After cartographical, geological and botanic recognition of the areas surrounding the studied mines, samples and consequent analysis and interpretation of the different materials were taken done: - superficial water and of mine drainage set, were collected for an year, in a monitored scheme with a bi-monthly periodic character, with $\mathrm{pH}$, temperature, Eh and conductivity determined in situ and chemical analysis of $\mathrm{SO} 4, \mathrm{HCO} 3, \mathrm{Ca}, \mathrm{K}, \mathrm{Mg}, \mathrm{Na}$, $\mathrm{Cl}, \mathrm{Ag}, \mathrm{As}, \mathrm{Bi}, \mathrm{Co}, \mathrm{Cu}, \mathrm{Fe}, \mathrm{Mn}, \mathrm{Ni}, \mathrm{Pb}, \mathrm{Zn}$ and $\mathrm{Cd}$ by AAS; - mineralized veins were studied in a transmitted and reflected light microscope and analysed by electronic microprobe; - various species of terrestrial plants and of their respective substrate (natural soils and tailings), and aquatic plants, destined to total chemical analysis (Fe, $\mathrm{Mn}, \mathrm{Cu}, \mathrm{Zn}, \mathrm{Pb}, \mathrm{Cr}, \mathrm{Co}, \mathrm{Ni}, \mathrm{Mo}, \mathrm{Cd}, \mathrm{Bi}, \mathrm{Sn}, \mathrm{W}, \mathrm{Ag}, \mathrm{As}$, $\mathrm{U})$ by ICP-MS; - some samples of the soils were targeted with a sequential selective chemical extraction in order to identify the metal partition along the mineral phases and measure their bioavailability.

\section{Results and Discussion}

The result indicated that the soil texture of the contaminated site was silty clay. The $\mathrm{CEC}$ and $\mathrm{pH}$ value of the topsoil was $13.2 \mathrm{cmol}(+) \mathrm{kg}^{-1}$ and in the levels of 5.6-7.2, respectively.

The Acid Mine Drainage (AMD) presents chemical characteristics which reflect lixiviation processes of mineralized mass which contain sulphides (Favas et al., 2012). Thus these waters are characterized as presenting low $\mathrm{pH}$ and high contents of sulphide and metals in solution. The superficial waters which circulate in the upstream areas of the mines are characterized by having $\mathrm{pH}$ close to neutral, relatively low conductivity and a low ionic charge. The downstream sampled waters of the mines and tailings distance themselves from these characteristics and draw themselves to those of AMD (Fig. 1). The samples which can be found under mine influence reveal a sulphated composition, while the 

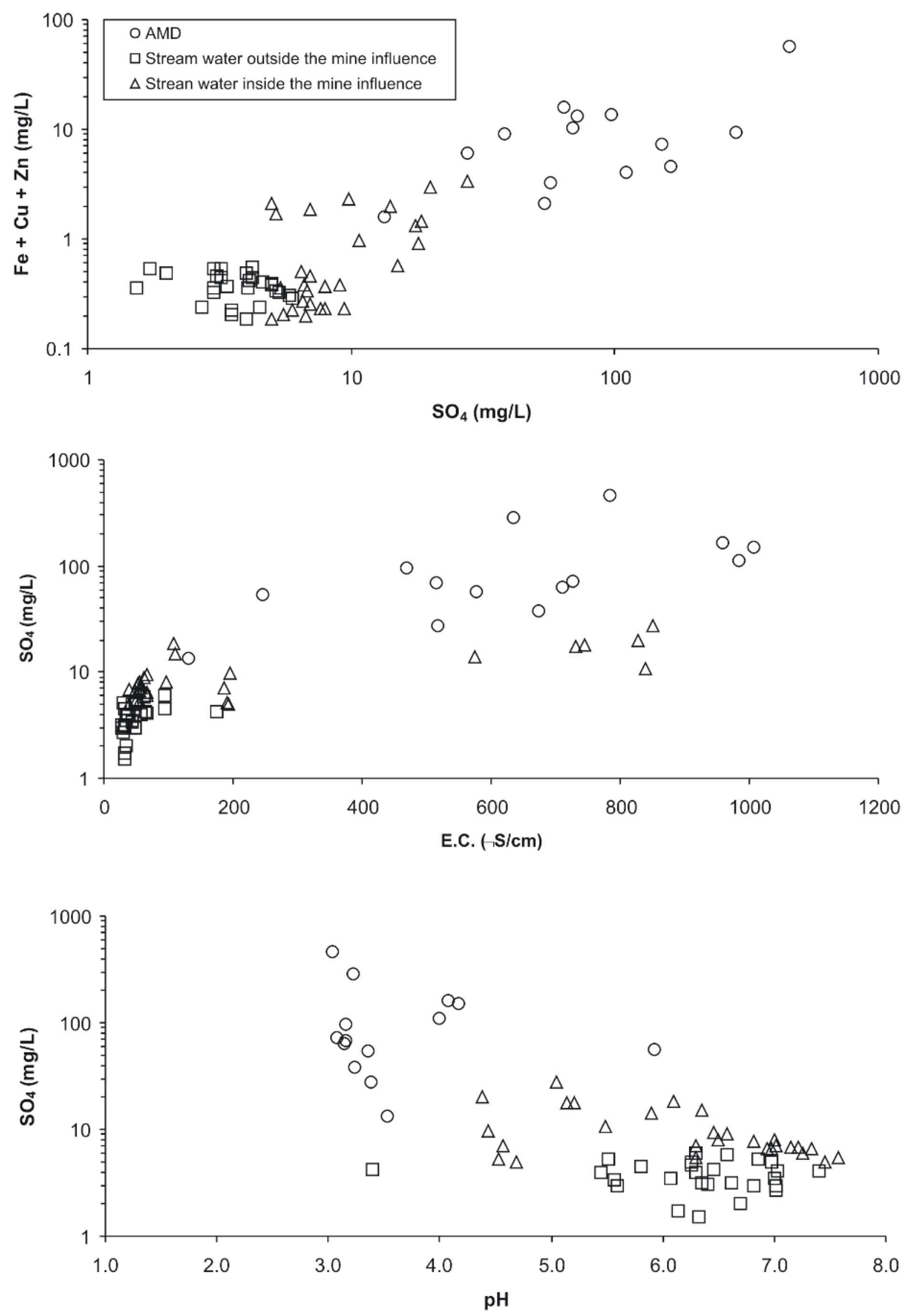

Fig. 1. $(\mathrm{Fe}+\mathrm{Cu}+\mathrm{Zn})$ vs. $\mathrm{SO}_{4}, \mathrm{SO}_{4}$ vs. electrical conductivity (E.C.) and $\mathrm{SO}_{4}$ vs. $\mathrm{pH}$ diagrams, for $\mathrm{AMD}$, and stream waters inside the mine influence and outside the mine influence. 
representative samples of the hydro-geochemical background hold a dominant bicarbonate character or chloride and sulphide.

The geochemical soils data show the anomalies in the dependency of the mineralization or the relation to mining influence. Beyond the mineral soils, it is shown that the highest registered levels, for the elements in general, are the soils involving the mineralized areas or the ones situated under tailings influence. The application of the Principal Components Analysis (PCA) verified the separation into element groups according to their behaviour as a function of $\mathrm{pH}$. Attributed to their geochemical behaviour, association amongst elements is verified amongst the five mines. The representative samples of the local geochemical background and the contaminated samples were discriminated (Fig. 2).

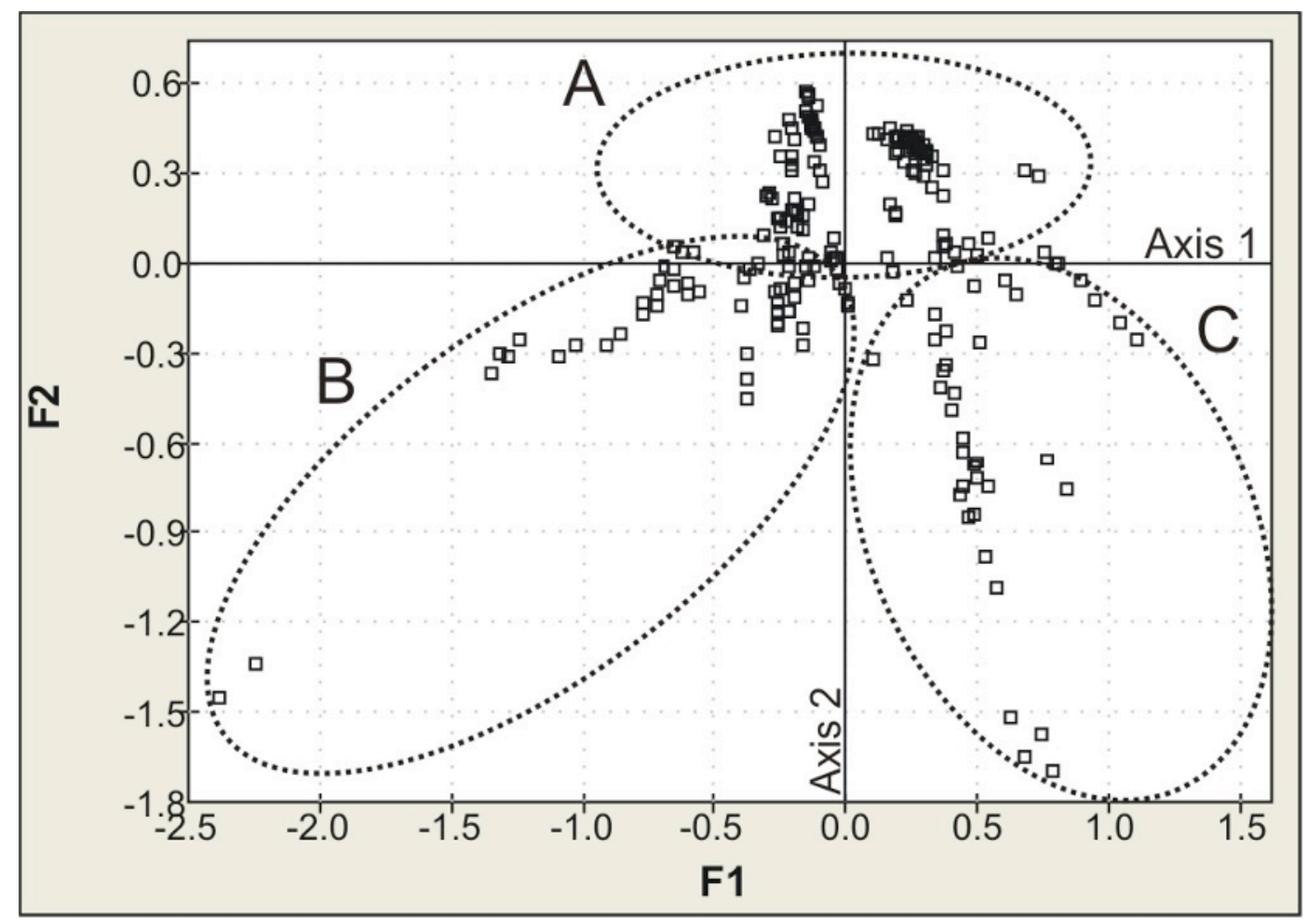

Fig. 2. Projection of the samples of soils in the two first Axes of the PCA. A- representative samples of geochemical background; B and C- samples with contamination.

The sequential selective chemical extraction verified that $\mathrm{pH}$ is the most important factor in the control of the geochemical distribution of the elements. Consequently a majority of the metallic cations $(\mathrm{Mn}, \mathrm{Cd}, \mathrm{Cu}, \mathrm{Zn}, \mathrm{Pb}, \mathrm{Co}$, $\mathrm{Cr}$, Ni) show an identical behaviour, presenting important enrichments in the most bioavailable fractions (water soluble and changeable), contrasting with the oxianions, as the As and the Mo, which evidence a lower mobility, due to adsorption to the Fe oxi- hydroxides, revealing important increase of reducible fractions (Favas et al., 2011).

Biochemical data show that the studied species are able to provide indications on the pedogeochemical contamination created by different mineralization. Meanwhile, according to the chemical elements present in the respective substrate, the provided answers differ whether its from species to species or from the type of organ considered. In every studied area each of the species (and organ) and element the biochemical behaviour in the soil-plant or water-plant system is interpreted, the respective bioaccumulation patterns are identified based on indicators as the Biological Absorption Coefficient (BAC) and the existing correlations, for each element, are as well evaluated, between total levels in the soils and vegetation material and amongst the bioavailability and bioacumulated fraction levels.

The study of aquatic plants focuses on the uptake of heavy metals, and arsenic by the specie Ranunculus peltatus Schrank, growing in the Tuela river in the vicinity of the abandoned tin mine of Ervedosa. The analytical data obtained demonstrate low pollutant concentrations in fluvial water. However, the trace elements are considerable concentrated in this aquatic plant samples. The heavy metal, and arsenic concentrations in the Ranunculus peltatus Schrank exceed the corresponding concentrations in the habitat (water) by tens of thousand times.

Al last, the potential application of the biogeochemical data is studied namely in the bioindication and fitoremediation domains. Based on the ratio of maximum concentration obtained for each element and the biogeochemical background, the types of physiological barriers present were determined and concluded on the bioindicator capacity of each species. To evaluate the studied plants' potential for the use in fitoremediation 
actions, extraction rates were determined having in mind the metal concentrations in their tissues in combination with the respective levels of biomass production.

\section{Conclusion}

We conclude that the species and organs best suited for biogeochemical indicating/prospecting, and/or with potential for mine restoration, in the studied areas are by order of importance: aerial tissues of Halimium umbellatum (L.) Spach, for As and W; leaves of Erica arborea $\mathrm{L}$. for $\mathrm{Bi}, \mathrm{Sn}, \mathrm{W}$ and mostly $\mathrm{Pb}$; stems of Erica arborea $\mathrm{L}$. for $\mathrm{Pb}$; needles of Pinus pinaster Aiton and aerial tissues of Pteridium aquilinum (L.) Kuhn for W; and leaves of Quercus faginea Lam. for Sn. These are the key stone species allowing biogeochemical delineation of areas of similar anomalous soil composition.
On the other hand, the aquatic plant studied (Ranunculus peltatus Schrank) can be used to decrease the heavy metals, and arsenic amounts into the aquatic environment affected by acid mine drainages.

\section{References}

Favas PJC, Pratas J, Gomes MP. Hydrochemistry of superficial waters in the Adoria mine area (Northern Portugal): environmental implications. Environmental Earth Sciences 2012; 65:363-372.

Favas PJC, Pratas J, Gomes MEP, Cala V. Selective chemical extraction of heavy metals in tailings and soils contaminated by mining activity: Environmental implications. J Geochemical Exploration 2011; 111:160-171. 